\title{
Lactic Acidosis and Mitochondrial Dysfunction in Two Children with Peroxisomal Disorders
}

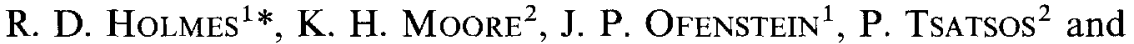 \\ F. L. KIECHLE ${ }^{1}$ \\ ${ }^{1}$ Departments of Pediatrics and Clinical Pathology, William Beaumont Hospital, \\ Royal Oak, MI 48073; '2Department of Chemistry, Oakland University, Rochester, \\ MI 48309, USA
}

Summary: Mitochondrial myopathies and defects in oxidative phosphorylation have been described in some patients with peroxisomal disorders. Although peroxisomes and mitochondria play a role in the $\beta$-oxidation of fatty acids, the metabolic interactions between the two are not well defined. Defects in peroxisomal $\beta$-oxidation are associated with extracellular accumulation of very long-chain fatty acids and may be accompanied by alterations in the intracellular pool of fatty acyl-CoAs, which are known to alter mitochondrial function. This study was initiated to examine alterations in the intracellular pool of acyl-CoAs and mitochondrial function in two children with generalized disorders of peroxisomal function and clinical lactic/pyruvic acidaemia. Fibroblasts were cultured from skin biopsies obtained from one child with neonatal adrenoleukodystrophy (NALD) and another with rhizomelic chondrodysplasia punctata (RCDP). Fibroblast lactate oxidation was significantly inhibited in NALD by $76 \%$ and RCDP by $92 \%$ compared to control values of $1.9 \pm 0.1 \mathrm{nmol} / \mathrm{min}$ per mg protein. Pyruvate dehydrogenase (PDH) (mean \pm SEM; activity nmol/ min per mg protein) was: NALD $0.55 \pm 0.02(p<0.01)$, RCDP $0.44 \pm 0.02$ $(p<0.01)$, and controls $0.83 \pm 0.02$. The acid-insoluble (long-chain and very long-chain) acyl-CoA levels (mean $\pm \mathrm{SEM}$; pmol/mg protein) were: NALD $129 \pm 69(p<0.01)$, RCDP $65 \pm 15(p<0.05)$, and control $45 \pm 7$. These two patients with generalized peroxisomal disorders exhibited an increase in intracellular acyl-CoA species accompanied by decreased PDH activity and clinical lactic/pyruvic acidaemia.

Isolation and biochemical characterization of peroxisomes began less than thirty years ago. Peroxisomes have multiple biosynthetic functions and, like mitochondria, play a role in the $\beta$-oxidation of fatty acids (Wanders et al 1990). The main function

*Correspondence: R.D. Holmes, Department of Pediatrics, University of Michigan Medical Center, Taubman Health Care Center, Box 0318 - Room 1924, 1500 E Medical Center Drive, Ann Arbor, MI 48109-0318, USA

MS received 8.10.92 Accepted 11.2.93 
of the peroxisomal oxidation system is the $\beta$-oxidation of very long-chain fatty acids (VLCFA), prostaglandins, dicarboxylic acids, xenobiotic fatty acids and hydroxylated 5 - $\beta$-cholestanoic acids (Schulz 1991). The products of peroxisomal $\beta$-oxidation, chainshortened acyl-CoAs, enter the mitochondrial $\beta$-oxidation pathway, promoting oxidative phosphorylation and supplying acetyl-CoA for ketogenesis.

The metabolic interaction between peroxisomes and mitochondria is not well defined. Goldfischer (1973) observed hyperlactataemia in two patients with peroxisomal disorders. In addition, abnormalities in the mitochondrial electron-transport chain in Zellweger syndrome have been described (Kelley and Corkey 1983; Trijbels et al 1983; Roels et al 1988), and patients with peroxisomal disorders have been reported to develop mitochondrial myopathies (Sarnat et al 1983; Wolff et al 1986). Abnormal oxidative phosphorylation has also been described in an infant with Zellweger syndrome (Muller-Hocker et al 1984).

Defects in peroxisomal $\beta$-oxidation are accompanied by an increase in the extracellular pool of fatty acids as indicated by increased plasma concentrations of VLCFA. It is not known whether there is a concurrent increase in the intracellular pool of acyl-CoAs that could affect mitochondrial function. Acyl-CoA molecules appear to have regulatory effects on a variety of reactions and have been shown to inhibit ureagenesis, gluconeogenesis and mitochondrial energy metabolism (Corkey and Deeney 1990). Long-chain acyl-CoAs have also been shown to inhibit the activity of pyruvate dehydrogenase complex, an enzyme composed of pyruvate dehydrogenase $\left(E_{1} ;\right.$ EC 1.2.4.1), dihydrolipoyl transacetylase $\left(E_{2} ; E C\right.$ 2.3.1.12) and dihydrolipoyl dehydrogenase ( $E_{3}$; EC 1.6.4.3) (Kiechle et al 1990b; Moore et al 1992). This study examines alterations in the intracellular pool of acyl-CoAs in cultured skin fibroblasts from two patients with peroxisomal disorders and their relation to mitochondrial metabolism.

\section{METHODS}

Patient 1: N.R. was born on 26 May 1983 following a full-term gestation. Birth weight was $3.13 \mathrm{~kg}$ ( 50 th percentile), length $54 \mathrm{~cm}$ (95th percentile) and head circumference $34.5 \mathrm{~cm}$ ( 50 th percentile). He was evaluated at 7 weeks of age because of failure to thrive and was noted to have hypotonia and enlarged anterior and posterior fontanelles with diastasis of the sagittal suture. Serum electrolytes were: sodium = $145 \mathrm{mmol} / \mathrm{L} \quad(139-146)$, potassium $=6.5 \mathrm{mmol} / \mathrm{L} \quad(4.0-6.2)$, chloride $=111 \mathrm{mmol} / \mathrm{L}$ $(96-106)$ and bicarbonate $=19 \mathrm{mmol} / \mathrm{L}(24-30)$. Serum lactic acid and pyruvic acid were elevated (Table 1). Hepatomegaly was present at age 4 months and serum aminotransferase levels were elevated (Table 1). Percutaneous liver biopsy showed abnormal lobular architecture with fibrous septa extending from portal tracts into the surrounding parenchyma. By 8 months of age he could not visually fix on objects and had wandering nystagmus. Ophthalmological evaluation revealed bilateral punctate cortical and plaque-like nuclear changes, optic atrophy and retinal degeneration.

A skin biopsy was performed at 1 year of age and fibroblasts were cultured, harvested and assayed for the activity of the peroxisomal membrane enzyme, dihydroxyacetone phosphate acyltransferase (DHAP-AT) (Datta et al 1984). The 
Table 1 Results of clinical laboratory tests

\begin{tabular}{lccc}
\hline Test & Reference range & NALD & RCDP \\
\hline Serum AST (U/L) & $20-45$ & 97 & 44 \\
Serum ALT (U/L) & $3-20$ & 39 & 14 \\
Plasma very long-chain fatty acids & $0.33 \pm 0.18$ & 1.49 & 0.36 \\
$\mathrm{C}_{26}(\mu \mathrm{g} / \mathrm{ml})$ & $0.01 \pm 0.01$ & 0.22 & 0.02 \\
$\mathrm{C}_{26} / \mathrm{C}_{22}$ & $<9.6$ & 9.8 & 12.2 \\
Plasma phytanate $(\mu \mathrm{mol} / \mathrm{L})$ & $35-55$ & 9 & 42 \\
Plasma carnitines & $45-65$ & 17 & 50 \\
$\quad$ Free $(\mu \mathrm{mol} / \mathrm{L})$ & $\mathrm{N}^{\mathrm{a}}$ & $\mathrm{N}$ & $\mathrm{N}$ \\
Total $(\mu \mathrm{mol} / \mathrm{L})$ & $\mathrm{ND}^{\mathrm{b}}$ & Adipic, suberic & $\mathrm{ND}$ \\
Urine acylcarnitine profile & $0.6-1.8$ & 2.8 & 2.1 \\
Urine organic acids & $30-70$ & 200 & 130 \\
Serum lactate $(\mathrm{mmol} / \mathrm{L})$ & & & \\
Serum pyruvate $(\mu \mathrm{mol} / \mathrm{L})$ & &
\end{tabular}

$\mathrm{NALD}=$ neonatal adenoleukodystrophy $\mathrm{RCDP}=$ rhizomelic chondrodysplasia punctata

${ }^{a} \mathrm{~N}=$ within the reference range determined by mass spectrometry at Duke University Medical Center, Pediatric Metabolism Laboratory

${ }^{\mathrm{b}} \mathrm{ND}=$ none detectable

activity was $30 \%$ of control (Wilson et al 1986). Levels of $\mathrm{C}_{26}$ VLCFA and the ratio of $\mathrm{C}_{26} / \mathrm{C}_{22}$ assayed at 20 months of age were elevated (Table 1). The phospholipid composition of erythrocytes was measured when the child was 2.5 years old. The erythrocyte phosphoethanolamine plasmalogen levels were $4 \%$ as compared to reference values of $12 \%$ (Wilson et al 1986) (Table 1). These results confirm the diagnosis of neonatal adrenoleukodystrophy (NALD; McKusick 20237).

The child is currently enrolled in special education classes with a level of development equivalent to a young toddler. He has not yet developed clinical or laboratory evidence of adrenal insufficiency (normal Cortrosyn stimulation test at age 8.5 years).

Patient 2: G.B. was born on 29 November 1989 by Caesarean section because of failure to progress and fetal distress. Gestational age was determined by physical examination at 33 weeks, birth weight $2.13 \mathrm{~kg}(<5$ th percentile) and length $43 \mathrm{~cm}$ $(<5$ th percentile). She had limb disproportion and radiographs showed rhizomelic shortening of the extremities, metaphyseal splaying, and punctate epiphyseal stippling diagnostic of rhizomelic chondrodysplasia punctata (RCDP; McKusick 21510). Bilateral nuclear cataracts were present.

At 1 month of age a sample of blood was sent to the Kennedy Institute for Handicapped Children (Baltimore, Maryland, USA) for analysis of erythrocyte plasmalogens and plasma VLCFA. Red blood cell plasmalogen levels were measured as dimethylacetal (DMA) and the ratio of DMA to the respective chain-length fatty acid was calculated. The mean value of $\mathrm{C}_{16}$-DMA/C ${ }_{16}$ fatty acid was 0.002 (reference range $0.065 \pm 0.010$ ) and $\mathrm{C}_{18}-\mathrm{DMCA} / \mathrm{C}_{18}$ fatty acid was 0.003 (reference range $0.195 \pm 0.035$ ). The ratio $\mathrm{C}_{26} / \mathrm{C}_{22}$ VLCFA was only slightly higher than normal (Table 1). A second sample was obtained at age 20 months and assayed for phytanic 
acid (Table 1). The depressed red blood cell plasmalogens, near normal levels of VLCFA and mildly elevated phytanic acid are consistent with the diagnosis of RCDP.

The infant underwent cataract surgery at 2 months of age and has been wearing corrective lenses. Serum electrolytes have been normal; however, serum lactic acid and pyruvic acid were found to be elevated at age 31 months (Table 1). Growth and development are delayed and she currently attends an early intervention school where she receives occupational and physical therapy.

Fibroblasts: Skin biopsies were performed on these two patients after obtaining informed consent from the parents and following guidelines established by the William Beaumont Hospital Human Investigation Committee. Biopsy specimens obtained from remnants of human foreskin removed from healthy infants undergoing routine circumcision and from adult volunteers were used as controls. Skin biopsy specimens were subcultured in Eagle's Minimum Essential Medium (MEM) (Mediatech, Washington, DC, USA) supplemented with $15 \%$ fetal bovine serum (Biocell, Carson, CA, USA), $100 \mathrm{U} / \mathrm{ml}$ penicillin $\mathrm{G}$ potassium, $100 \mu \mathrm{g} / \mathrm{ml}$ streptomycin sulphate (Gibco, Grand Island, NY, USA) and $100 \mu \mathrm{U} / \mathrm{ml}$ insulin (Sigma, St Louis, MO, USA). Fibroblasts were grown as monolayer cultures and maintained in a $37^{\circ} \mathrm{C}$ humidified incubator containing a mixture of $95 \%$ air and $5 \% \mathrm{CO}_{2}$. Medium was replaced twice a week and cells passed during their log growth phase. Cultures were routinely screened for mycoplasma contamination by Mycotrim TC (Hanna Biologicals Inc., Alameda, CA, USA).

Lactate oxidation: An assay was developed to screen for mitochondrial metabolic dysfunction by measuring oxidation of lactate by fibroblasts. Metabolism of $\mathrm{D}, \mathrm{L}-\mathrm{C} 1-$ ${ }^{14} \mathrm{C}$ llactate was measured in fibroblast monolayers grown to confluence in $25-\mathrm{cm}^{2}$ tissue flasks containing MEM. Fibroblasts were washed twice with phosphatebuffered saline then treated with phosphate-buffered saline containing $25 \mu \mathrm{mol} / \mathrm{L}$ L-lactate (Sigma) and $0.1 \mu \mathrm{Ci} / \mathrm{ml} \mathrm{D,L-}\left[1-{ }^{14} \mathrm{C}\right]$ lactate (American Radiochemical Co., St. Louis, MO, USA) and slowly shaken at $37^{\circ} \mathrm{C}$ for $2 \mathrm{~h} 40 \mathrm{~min}$. Filter paper moistened with $0.2 \mathrm{ml}$ of $100 \mathrm{~g} / \mathrm{L}$ sodium hydroxide, used to collect atmospheric ${ }^{14} \mathrm{CO}_{2}$, was suspended in the flask with an airtight stopper directly above the fibroblast monolayer. Each filter was transferred into scintillation vials and the amount of ${ }^{14} \mathrm{CO}_{2}$ liberated was determined. The cells were then harvested for protein determination. Activity was expressed as nmol ${ }^{14} \mathrm{CO}_{2}$ released per min per mg cellular protein. Background activity determined using flasks with no cells and containing only $0.1 \mu \mathrm{Ci} \mathrm{D,L}-[1-$ ${ }^{14} \mathrm{C}$ lactate in $1 \mathrm{ml}$ phosphate-buffered saline was subtracted from both the control and patient results.

Pyruvate dehydrogenase (PDH): Fibroblasts were harvested 3-4 days after reaching confluence. Two $150-\mathrm{cm}^{2}$ tissue flasks, containing approximately $3.0 \times 10^{7}$ cells, were washed three times with calcium-free and magnesium-free phosphate-buffered saline ( $\mathrm{pH}$ 7.4). After the final wash, $2 \mathrm{ml}$ homogenization buffer containing $25 \mathrm{mmol} / \mathrm{L}$ sodium fluoride, $4 \mathrm{mmol} / \mathrm{L}$ dichloracetic acid, $1 \mathrm{mmol} / \mathrm{L}$ dithiothreitol and $0.25 \mathrm{mmol} / \mathrm{L}$ sucrose in $40 \mathrm{mmol} / \mathrm{L}$ phosphate-buffered saline $(\mathrm{pH} 7.4)$ was added to 
the monolayers. The cells were transferred into 5-ml cryogenic vials. The sample was homogenized using a glass Potter-Elvehjem homogenizer at setting 6 for 6 seconds. The cell homogenate was further frozen and thawed three times in a dry-ice-acetone bath and centrifuged for $15 \mathrm{~min}$ at $35000 \mathrm{~g}$ in a refrigerated Beckmann J2-21 centrifuge. The supernatants were maintained on ice and assayed immediately for PDH activity and total protein determination (Smith et al 1985). The phosphorylation state of the PDH complex was stabilized by treatment of the fibroblasts with dichloracetic acid to inhibit PDH kinase (EC 2.7.1.99) (Whitehouse et al 1974) and sodium fluoride to inhibit the PDH phosphatase (EC 3.1.3.43) (Hucho et al 1972).

A radiochemical method based on the specific decarboxylation of $\left[1-{ }^{14} \mathrm{C}\right]$ pyruvate to ${ }^{14} \mathrm{CO}_{2}$ has been employed in the measurement of $\mathrm{PDH}$ activity. However, [1${ }^{14} \mathrm{C}$ ]pyruvate is unstable and undergoes spontaneous non-enzymatic decarboxylation that may reduce the sensitivity of the assay (Williams et al 1978; Constantopoulos and Barranger 1984; Kiechle et al 1990a). An assay was developed by Schofield et al (1980) to overcome these problems using in situ generation of $\left[1-^{14} \mathrm{C}\right]$ pyruvate from $\left[1-{ }^{14} \mathrm{C}\right]$ lactate and is modified as described by Buffington et al (1984), who added two phosphorylation/dephosphorylation inhibitors of PDH complex, NaF and DCA, to measure $\mathrm{PDH}$ activity at the time of homogenization.

The assay mixture containing $50 \mathrm{mmol} / \mathrm{L}$ potassium phosphate buffer $(\mathrm{pH} \mathrm{7.4),}$ $2.5 \mathrm{mmol} / \mathrm{L} \mathrm{MgCl}_{2}, 1.5 \mathrm{mmol} / \mathrm{L} \beta$-nicotinamide-adenine dinucleotide, $500 \mu \mathrm{mol} / \mathrm{L}$ $\mathrm{CaCl}_{2}, 80 \mu \mathrm{mol} / \mathrm{L}$ thiamine pyrophosphate, $100 \mathrm{mU} / \mathrm{ml}$ phosphotransacetylase, $0.2 \mathrm{mmol} / \mathrm{L}$ coenzyme A (CoASH), $1 \mathrm{mmol} / \mathrm{L}$ dithiothreitol and the fibroblast suspension $(20-100 \mu \mathrm{l})$ containing $0.05-0.25 \mathrm{mg}$ protein was preincubated for $10 \mathrm{~min}$ at $37^{\circ} \mathrm{C}$. The reaction was started by adding $10 \mathrm{IU}$ L-lactate dehydrogenase, $1.1 \mathrm{mmol} / \mathrm{L}$ L-lactate and $0.1 \mu \mathrm{Ci} / \mathrm{ml} \mathrm{D,L}-\left[1-{ }^{14} \mathrm{C}\right]$ lactate to the assay mixture for a total volume of $0.5 \mathrm{ml}$. Filter paper moistened with $0.2 \mathrm{ml}$ of $100 \mathrm{~g} / \mathrm{L}$ sodium hydroxide, used for trapping ${ }^{14} \mathrm{CO}_{2}$, was then suspended in a vial with an airtight stopper directly over the assay mixture. This linear reaction (Hansen 1982) was stopped after $60 \mathrm{~min}$ at $37^{\circ} \mathrm{C}$ by addition of $3 \mathrm{~mol} / \mathrm{L} \mathrm{H}_{2} \mathrm{SO}_{4}$. Incubation continued for $30 \mathrm{~min}$ at $37^{\circ} \mathrm{C}$ and the filter paper was transferred to a vial containing scintillation fluid for the determination of ${ }^{14} \mathrm{CO}_{2}$ liberated.

Experiments were performed in triplicate. 'Blank' values were obtained from identical assay tubes without CoASH and $\beta$-nicotinamide-adenine dinucleotide. PDH activity is expressed as $\mathrm{nmol}{ }^{14} \mathrm{CO}_{2}$ released per min per $\mathrm{mg}$ of homogenate protein. Values are expressed as the mean \pm SEM.

Citrate synthase and catalase: For the determination of citrate synthase (EC 4.1.3.7), catalase (EC 1.11.1.6), acyl-CoA synthetase $\left(\mathrm{C}_{4}\right.$ to $\mathrm{C}_{11}, \mathrm{EC}$ 6.2.1.2; $\mathrm{C}_{6}$ to $\mathrm{C}_{20}, \mathrm{EC}$ 6.2.1.3), acyl-CoA hydrolase, and acyl-CoA levels, the fibroblasts were prepared in the same manner. Frozen packed cells were dispersed in 3 volumes of ice-cold $0.25 \mathrm{~mol} / \mathrm{L}$ sucrose- $0.01 \mathrm{mmol} / \mathrm{L}$ potassium phosphate buffer $(\mathrm{pH} 7.4$ ) and homogenized for $40 \mathrm{~s}$ with a Tissue-Tearer at the lowest setting. Aliquots of homogenate were used for protein assay, enzyme assay, and CoA determinations. Standard spectrophotometric assays were employed for assay of citrate synthase (EC 4.1.3.7) (Shepherd et al 1969) and catalase (EC 1.11.1.6) (Johansson and Hakan Borg 1988). 
Acyl-CoA synthetase: Incubation mixture $(0.25 \mathrm{ml})$ containing $100 \mathrm{mmol} / \mathrm{L}$ Tris$\mathrm{HCl}$ buffer $(\mathrm{pH} 8.0), 150 \mathrm{mmol} / \mathrm{L} \mathrm{KCl}, 15 \mathrm{mmol} / \mathrm{L} \mathrm{MgCl}_{2}, 1 \mathrm{mmol} / \mathrm{L} \mathrm{CoASH}$, $10 \mathrm{mmol} / \mathrm{L}$ adenosine triphosphate and $1 \mathrm{mmol} / \mathrm{L}\left[1-{ }^{14} \mathrm{C}\right]$ palmitate $-0.2 \mathrm{mmol} / \mathrm{L}$ albumin was added to tubes containing $0.12 \mathrm{mg}$ of fibroblast homogenate. The reaction proceeded in a linear manner for $20 \mathrm{~min}$ at $37^{\circ} \mathrm{C}$ and was terminated by addition of $0.5 \mathrm{ml}$ Dole reagent (Hosaka et al 1981). Unreacted substrate was removed by repeatid heptane extractions. Aliquots of the remaining aqueous layer were dissolved in scintillation fluid and counted.

Acyl-CoA hydrolase: The assay was performed by incubating $20 \mu \mathrm{g}$ tissue in $0.7 \mathrm{ml}$ of reaction mixture which contained $100 \mathrm{mmol} / \mathrm{L}$ Tris- $\mathrm{HCl}$ buffer ( $\mathrm{pH} \mathrm{7.4),}$ $1.25 \mathrm{mmol} / \mathrm{L} 5,5^{\prime}$-dithiobis-(2-nitrobenzoic acid), and $40 \mu \mathrm{mol} / \mathrm{L}$ acyl-CoA. The reaction of released $\mathrm{CoASH}$ with 5,5'-dithiobis-(2-nitrobenzoic acid) was monitored at $412 \mathrm{~nm}$ by the rate analysis program of the Milton-Roy Diode Array Spectrophotometer (Berge and Farstad 1979). The acyl-CoA substrates were prepared as $0.5 \mathrm{mmol} / \mathrm{L}$ stock solutions in deionized water. Concentrations were confirmed by absorption at $260 \mathrm{~nm}$.

CoA levels: Immediately after preparation, aliquots of fibroblast homogenate were extracted with ice-cold perchloric acid $(6 \% \mathrm{v} / \mathrm{v}$, final concentration) to separate soluble $\mathrm{CoA}$ moieties (CoASH and acetyl-CoA) from acid-insoluble long-chain and very long-chain acyl-CoA moieties. The acid-insoluble acyl-CoA pellets were washed, resuspended, hydrolysed, and neutralized as previously described (Moore et al 1982). The acid-soluble supernatant was neutralized and assayed directly for CoASH plus acetyl-CoA and, after treatment with $N$-ethylmaleimide, for direct analysis of acetylCoA (Allred and Guy 1969). The sensitive fluorimetric enzymatic cycling method of Veloso and Veech (1974) was used to assay neutralized fractions. Free CoASH content was estimated by subtracting acetyl-CoA content from total acid-soluble content.

Total protein: Protein content was determined by the bicinchoninic acid assay (Smith et al 1985).

Statistical significance: Statistical significance was assigned to data with $p<0.05$ as determined by the unpaired Student's $t$-test.

\section{RESULTS}

Fibroblasts from the patients and two infant controls were screened for their ability to oxidize lactate (Table 2). The infant control values represent the average of two controls each assayed in triplicate. Lactate oxidation was significantly decreased in NALD (76\% inhibition) and RCDP ( $92 \%$ inhibition) compared to the infant control value of $1.9 \pm 0.1 \mathrm{nmol} / \mathrm{min}$ per $\mathrm{mg}$ protein. These results suggested that the mitochondrial oxidation of pyruvate to $\mathrm{CO}_{2}$ by $\mathrm{PDH}$ was decreased in both of the patients' fibroblasts. Therefore, PDH activity was determined. PDH activity was significantly decreased in the NALD fibroblasts (34\% inhibition) and the RCDP 
Table 2 Lactate oxidation and pyruvate dehydrogenase activity in fibroblasts

\begin{tabular}{lcc}
\hline Fibroblasts & $\begin{array}{c}\text { Lactate oxidation } \\
\text { (nmol/min per mg protein) }\end{array}$ \\
\hline Control & $1.9 \pm 0.1$ & $0.83 \pm 0.02$ \\
NALD & $0.45 \pm 0.015^{\mathrm{a}, \mathrm{b}}$ & $0.55 \pm 0.02^{\mathrm{c}}$ \\
RCDP & $0.14 \pm 0.003^{\mathrm{a}}$ & $0.44 \pm 0.02^{\mathrm{c}}$ \\
\hline
\end{tabular}

Results from a representative experiment were performed in triplicate. The results represent the mean $\pm S E M$. Similar results were obtained in at least 3 additional experiments

${ }^{a} p<0.0005$, compared with infant controls

${ }^{\mathrm{b}} p<0.05$, compared with RCDP

${ }^{c} p<0.01$, compared with infant controls

fibroblasts ( $47 \%$ inhibition) as compared with the infant control value of $0.83 \pm 0.02 \mathrm{nmol} / \mathrm{min}$ per $\mathrm{mg}$ protein (Table 2). The location of PDH on the inner mitochondrial membrane suggests that the decrease in activity observed in NALD and RCDP is attributable to mitochondrial dysfunction. Since PDH activity can be inhibited in vitro by a variety of acyl-CoA species (Kiechle et al 1990b; Moore et al 1992), the acyl-CoA concentration in the fibroblasts was determined.

The distributions of CoA species for infant and adult controls and patient fibroblasts are shown in Table 3 . The infant controls and patients were more closely age-matched and their results were compared. Fibroblasts derived from NALD had acid-insoluble acyl-CoA levels, including acyl-CoA with chain length $>\mathrm{C}_{8}$, almost 3-fold higher than those found in infant control fibroblasts. NALD fibroblasts also demonstrated a 2.2-fold increase in acetyl-CoA content; in contrast, the free CoASH in these fibroblasts was only $6 \%$ of infant control fibroblasts. Total CoA (acid-insoluble acyl$\mathrm{CoA}+$ acetyl CoA + CoASH) was elevated almost 2-fold in NALD. The increased esterified $\mathrm{COA}$ and decreased free CoASH result in dramatic increases in both acetyl$\mathrm{CoA} / \mathrm{CoASH}$ and acid-insoluble acyl-CoA/CoASH ratios in NALD fibroblasts.

Table 3 Fibroblast coenzyme A levels

\begin{tabular}{lcccc}
\hline CoA species & Infant controls & $\begin{array}{c}\text { Adult controls } \\
\text { (pmol/mg protein) }\end{array}$ & RALD \\
\hline Acid-insoluble acyl-CoA & $45 \pm 7$ & $45 \pm 11$ & $129 \pm 69^{\mathrm{a}}$ & $65 \pm 15^{\mathrm{b}}$ \\
CoASH + acetyl-CoA & $163 \pm 37$ & $154 \pm 40$ & $261 \pm 64$ & $194 \pm 72$ \\
Acetyl-CoA & $115 \pm 40$ & $108 \pm 24$ & $258 \pm 77^{\mathrm{a}}$ & $137 \pm 45$ \\
CoASH & 48 & 46 & 3 & 57 \\
Total CoA & 208 & 199 & 390 & 259 \\
Ratios & & & & \\
Acetyl-CoA/CoASH & 2.40 & 2.35 & 86.0 & 2.40 \\
Acyl-CoA/CoASH & 0.94 & 0.98 & 43.0 & 1.14 \\
\hline
\end{tabular}

Acid-insoluble acyl-CoA species represent those with chain length $>\mathrm{C}_{8: 0}$

Metabolite levels are expressed as pmol $/ \mathrm{mg}$ protein. The data are means of 3 or more determinations \pm SD ${ }^{\mathrm{a}} p<0.01,{ }^{\mathrm{b}} p<0.05$, when compared with infant controls 
RCDP fibroblasts had a total CoA content $25 \%$ greater than that observed for infant controls. The most significant change was a $44 \%$ increase in the long-chain acyl-CoA level. Despite the modest enhancement in the CoA content, the acetyl $\mathrm{CoA} / \mathrm{CoASH}$ ratio was identical for both infant control and RCDP fibroblasts, but the long-chain acyl-CoA/CoASH was slightly elevated in RCDP fibroblasts. It should be noted that this study did not include quantitation of acid-soluble short- and medium-chain acyl-CoA species. Under most conditions these acyl-CoA species represent a very minor component of the total CoA pool (Moore et al 1988).

Fibroblasts from both patients contained normal or enhanced levels of both mitochondrial (citrate synthase) and peroxisomal (catalase) marker enzymes (Table 4). In addition, fibroblast homogenates were assayed for levels of enzymes involved in formation (acyl-CoA synthetase) and degradation (acyl-CoA hydrolase) of intracellular acyl-CoA species (Table 4). Acyl-CoA synthetase was determined with a single substrate, palmitic acid $(16: 0)$, while three substrates, octanoyl-CoA $(8: 0)$, palmitoylCoA (16:0), and erucoyl-CoA (22:0), were employed in the acyl-CoA hydrolase assays. As seen in Table 4, the NALD fibroblasts had infant control levels of acylCoA synthetase as well as medium- and long-chain acyl-CoA hydrolase; however, the very long-chain acyl-CoA hydrolase activity was elevated 2.8 -fold compared with the infant control. The RCDP fibroblasts exhibited a $36 \%$ decrease in palmitoylCoA synthetase (EC 6.2.1.3) activity and a 2.7 -fold increase in the very long-chain acyl-CoA hydrolase activity.

\section{DISCUSSION}

Two children with peroxisomal disorders were found to have moderate lactic and pyruvic acidaemia, prompting this investigation of the interrelationship of mitochondrial and peroxisomal function. Lactic and pyruvic acidaemia are not described in patients with peroxisomal disorders, but previous findings suggest that these patients have altered mitochondrial function (Sarnat et al 1983; Wolff et al 1986; Muller-Hocker et al 1984). Goldfischer et al (1973) first reported that patients with Zellweger syndrome lacked peroxisomes. Mitochondrial morphology was not

\section{Table 4 Fibroblast enzyme levels}

\begin{tabular}{lcccc}
\hline Activity & Infant controls & \multicolumn{1}{c}{$\begin{array}{c}\text { Adult controls } \\
\text { (nmol/min per mg protein) }\end{array}$} & RCDP \\
\hline Catalase & $6.85 \pm 1.40$ & $7.63 \pm 1.80$ & $11.98 \pm 2.39$ & $7.60 \pm 3.77$ \\
Citrate synthase & $29.80 \pm 2.65$ & $36.52 \pm 9.17$ & $27.10 \pm 13.16$ & $34.90 \pm 2.40$ \\
Acyl-CoA synthetase & $2.48 \pm 0.56$ & $1.98 \pm 0.68$ & $2.64 \pm 0.71$ & $1.58 \pm 0.50^{\mathrm{b}}$ \\
Acyl-CoA hydrolase & & & & \\
$\mathrm{C}_{8: 0}$ & $18.93 \pm 6.50$ & $16.21 \pm 7.22$ & $14.02 \pm 7.55$ & $13.36 \pm 6.77$ \\
$\mathrm{C}_{16: 0}$ & $22.59 \pm 11.53$ & $16.84 \pm 4.61$ & $17.23 \pm 9.74$ & $16.25 \pm 7.21$ \\
$\mathrm{C}_{22: 0}$ & $1.88 \pm 1.41$ & & $5.32 \pm 2.71^{\mathrm{a}}$ & $5.02 \pm 1.89^{\mathrm{a}}$ \\
\hline
\end{tabular}

Enzyme activities are expressed as $\mathrm{nmol} / \mathrm{min}$ per $\mathrm{mg}$ protein. The data are means of 3 or more determinations $\pm \mathrm{SD}$

${ }^{\mathrm{a}} p<0.01,{ }^{\mathrm{b}} p<\overline{0.05}$, when compared with infant controls 
described but cytochemical studies of intact brain mitochondria demonstrated reduced capability to oxidize succinate.

Clinical and biochemical results suggest that our patients with peroxisomal disorders and acidosis have mitochondrial dysfunction. The conversion of radiolabelled lactate to radiolabelled $\mathrm{CO}_{2}$ appears to represent an excellent screening assay for potential metabolic errors that may lead to clinical lactic acidosis (Kerr 1991). Reduced PDH activity is the most common cause of congenital lactic acidosis and affected children present with a variable clinical picture (Robinson et al 1987). The NALD and RCDP patients both demonstrated decreased lactate oxidation and decreased PDH activity.

Biochemical studies utilizing mitochondria in liver and muscle cells from patients with peroxisomal disorders have confirmed a defect in the electron-transport chain before the oxidative step involving cytochromes (Versmold et al 1977; Trijbels et al 1983). Alterations in the biosynthesis of cell membranes (Poulos 1989; Naider and Moser 1990; Wanders et al 1990) and the accumulation of amphiphilic very longchain acyl-CoA in peroxisomal disorders may lead to a disturbance in the structure of the inner mitochondrial membrane causing defects in the electron-transport chain (Trijbels 1983). The results of our studies utilizing fibroblasts show that the reactions localized to the inner mitochondrial membrane, i.e. the conversion of lactate to $\mathrm{CO}_{2}$ and PDH activity, are suppressed in NALD and RCDP. These results imply that the heterogeneous clinical presentation of patients with peroxisomopathies may be related to the degree of associated secondary mitochondrial dysfunction.

Mitochondrial dysfunction may occur secondary to the intracellular accumulation of acyl-CoA species (Corkey et al 1988; Corkey and Deeney 1990). In the NALD and RCDP patients the acid-insoluble acyl-CoA concentration (long-chain and very long-chain species) is significantly increased compared to the infant and adult controls. Palmitoyl-CoA in the micromolar concentration range alters a variety of mitochondrial functions, like the activity of the $\mathrm{pH}$-dependent anion-conducting channel (Halle-Smith et al 1988), steady-state transmembrane potentials (diLisa et al 1989), PDH activity (Smith and Saggerson 1979; Lai et al 1989; Kiechle et al 1990a,b; Moore et al 1992), and other mitochondrial dehydrogenases (Lai and Cooper 1991). These experiments measuring $\mathrm{PDH}$ activity were performed in the absence of adenosine triphosphate, the substrate for the PDH kinase, excluding this enzyme as the mediator of the inhibition of mitochondrial PDH activity (Smith and Saggerson 1979; Lai et al 1989; Lai and Cooper 1991). Other acyl-CoA species have been reported to inhibit (butyryl-CoA) or stimulate (malonyl-CoA, acetoacetyl-CoA, propionyl-CoA) PDH kinase activity by covalent acylation (Rahmatullah and Roche 1985). The acetyl-CoA/CoASH is markedly increased in NALD compared to infant control (Table 3). This increased ratio is sufficient to activate PDH kinase in vitro, phosphorylate the enzyme complex and reduce activity (Denton et al 1978). This mechanism alone or in combination with mitochondrial damage induced by amphiphilic acyl-CoA may contribute to the decreased PDH activity observed in NALD. However, in RCDP this ratio is equivalent to the control, suggesting that the elevation in long-chain and very long-chain acyl-CoA species alone may be responsible for the inhibition of PDH activity. 
To complement the above findings, we investigated the activity of a group of enzymes with the potential of altering mitochondrial and peroxisomal acyl-CoA pools. Homogenate acyl-CoA synthetase activity was assessed using palmitic acid as substrate (Table 4). Palmitoyl-CoA synthetase has a mitochondrial (21\%), peroxisomal $(16 \%)$, and microsomal $(60 \%)$ distribution in liver (Bronfman et al 1984). There is evidence that separate long-chain and very long-chain acyl-CoA synthetases are found in peroxisomes (Lageweg et al 1991). Lazo et al (1988) propose that deficiency of the peroxisomal very long-chain acyl-CoA synthetase is responsible for the impaired oxidation of very long-chain fatty acids by fibroblasts from patients with X-linked adrenoleukodystrophy. Our NALD patient had normal levels of the palmitoyl-CoA synthetase in spite of dramatically elevated intracellular acyl-CoA levels. It is possible that the elevated acyl-CoA pool is due primarily to very long-chain acyl-CoAs that may alter the very long-chain acyl-CoA synthetase activity by feedback inhibition. The RCDP patient had significantly reduced levels of long-chain acyl-CoA synthetase, which may have prevented the dramatic acyl-CoA accumulation seen with the NALD patient.

The activity of acyl-CoA hydrolase was elevated in both NALD and RCDP in the presence of very long-chain erucoyl-CoA substrate (Table 4). It is likely that this specific elevation was induced by accumulated very long-chain acyl-CoAs. Moore et al (1988) observed an increase in medium-chain acyl-CoA hydrolase activity subsequent to medium-chain acyl-CoA accumulation due to valproic acid (2-propylpentanoic acid) feeding, and Kurooka et al (1971) correlated increased long-chain acylCoA hydrolase activity with the increased long-chain acyl-CoA content due to alloxan diabetes. As the long-chain acyl-CoA hydrolase activity (determined with palmitoyl$\mathrm{CoA}$ ) was not elevated in patients, it appears that there is a specific very long-chain acyl-CoA hydrolase enzyme. In light of the proposed role of acyl-CoA hydrolases as regulators of intracellular CoA pools (Berge and Aarsland 1985), it appears that both patients are hydrolysing very long-chain acyl-CoAs in order to maintain a normal CoASH concentration; the RCDP patient has achieved this metabolic goal, while the NALD patient, with a severely restricted CoASH pool, has been unsuccessful. Another indication of the metabolic response to the stress of accumulating acyl-CoAs is the expanded total CoA content found in the NALD fibroblasts. Increases in total CoA have also been correlated with enhanced acyl-CoA hydrolase activities (Moore et al 1988; Kurooka et al 1971).

These two patients with peroxisomal disorders, NALD and RCDP, and moderate hyperlactataemia have been shown to exhibit decreased PDH activity which may be related to alterations in the pool of acyl-CoA species within the cell. These patients also exhibit alterations in the activity of enzymes involved in regulating the size of the acyl-CoA pool. These results suggest that the heterogeneity observed in the clinical presentation of the various peroxisomal disorders or within a specific peroxisomal disorder, as has been confirmed by complementation studies (Roscher et al 1989), may be related to the degree of mitochondrial dysfunction.

\section{ACKNOWLEDGEMENTS}

The authors thank Judi Kreiselmeier and Teresa Xedos for preparing the manuscript and Diane Dandurand for performing the protein assay. This work was supported 
by a grant from the William Beaumont Hospital Research Institute and Children's Miracle Network Telethon.

\section{REFERENCES}

Allred JB, Guy DG (1969) Determination of coenzyme A and acetyl CoA in tissue extracts. Anal Biochem 29: 293-299.

Berge RK, Aarsland A (1985) Correlation between the cellular level long-chain acyl-CoA, peroxisomal $\beta$-oxidation, and palmitoyl-CoA hydrolase activity in rat liver. Biochim Biophys Acta 837: 141-151.

Berge RK, Farstad M (1979) Purification and characterization of long-chain acyl-CoA hydrolase from rat liver mitochondria. Eur $J$ Biochem 96: 393-401.

Bronfman M, Inestrosa NC, Nervi FO, Leighton F (1984) Acyl-CoA synthetase and the peroxisomal enzymes of $\beta$-oxidation in human liver. Biochem $J$ 224: 709-720.

Buffington CK, Stentz FB, Kitabchi AE (1984) Activation of pyruvate dehydrogenase complex by porcine and biosynthetic insulin in cultured human fibroblasts. Diabetes 33: 681-685.

Constantopoulos G, Barranger JA (1984) Nonenzymatic decarboxylation of pyruvate. Anal Biochem 139: 353-358.

Corkey BE, Deeney JT (1990) Acyl CoA regulation of metabolism and signal transduction. In Coates P, Tanaka K, eds. Fatt Acid Oxidation: Clinical, Biochemical and Molecular Aspects. New York: Alan R. Liss, 217-232.

Corkey BE, Hale DE, Glennon MC et al (1988) Relationship between unusual hepatic acyl coenzyme A profiles and the pathogenesis of Reye syndrome. $J$ Clin Invest 82: 782-788.

Datta NS, Wilson GN, Hajra AK (1984) Deficiency of enzymes catalyzing the biosynthesis of glycerol-ether lipids in Zellweger syndrome: A new category of metabolic disease involving the absence of peroxisomes. $N$ Engl J Med 311: 1080-1083.

Denton RM, Hughes WA, Bridges BJ, Brownsey RW, McCormack JG, Stansbie D (1978) Regulation of mammalian pyruvate dehydrogenase by hormones. Horm Cell Regul 2: 191-208.

di Lisa F, Menabo R, Miotto G, Bobylera-Guarriero V, Siliprandi N (1989) $\mathrm{Ca}^{+2}$-mediated action of long chain acyl-CoA on liver mitochondria energy linked processes. Biochim Biophys Acta 973: 185-188.

Goldfischer S, Moore CL, Johnson AB et al (1973) Peroxisomal and mitochondrial defects in the cerebro-hepato-renal syndrome. Science 182: 62-64.

Halle-Smith SC, Murray AG, Selwyn MJ (1988) Palmitoyl-CoA inhibits the mitochondrial inner membrane anion-conducting channel. FEBS 236: 155-158.

Hansen TL (1982) Determination of pyruvate dehydrogenase in cultured human fibroblasts and amniotic fluid cells. Clin Chim Acta 123: 45-50.

Hosaka K, Mishira M, Kamiryo T, Numa S (1981) Long-chain acyl-CoA synthetases I and II from Candida lipolytica. Methods Enzymol 71: 325-333.

Hucho F, Randall DD, Roche TE, Burgett MW, Pelley JW, Reed LJ (1972) Alpha-keto acid dehydrogenase complexes. XVII. Kinetic and regulatory properties of pyruvate dehydrogenase kinase and pyruvate dehydrogenase phosphatase from bovine kidney and heart. Arch Biochem Biophys 151: 328-340.

Johansson LH, Hakan Borg LA (1988) A spectrophotometric method for determination of catalase activity in small tissue samples. Anal Biochem 174: 331-336.

Kelley RI, Corkey BE (1983) Increased sensitivity of cerebrohepatorenal syndrome fibroblasts to antimycin A. J Inher Metab Dis 6: 158-162.

Kerr DS (1991) Lactic acidosis and mitochondrial disorders. Clin Biochem 24: 331-336.

Kiechle FL, Malinski H, Dandurand D, McGill JB (1990a) The effect of amino acids, monoamines and polyamines on pyruvate dehydrogenase activity in mitochondria from rat adipocytes. Mol Cell Biochem 93: 195-206. 
Kiechle FL, Malinski T, Moore KH (1990b) Insulin action: Implications for the clinical laboratory. Lab Med 21: 565-573.

Kurooka S, Hosoki K, Yoshimura Y (1971) Increase in long-chain fatty acyl-CoA hydrolase activity in the liver and kidney of alloxan diabetic rat. $J$ Biochem 69: 247-249.

Lageweg W, Wanders RJA, Tager TM (1991) Long-chain-acyl-CoA synthetase and very-longchain-acyl-CoA synthetase activities in peroxisomes and microsomes from rat liver. An enzymological study. Eur J Biochem 196: 519-523.

Lai JCK, Cooper AJL (1991) Neurotoxicity of ammonia and fatty acids: Differential inhibition of mitochondrial dehydrogenases by ammonia and fatty acyl coenzyme A derivatives. Neurochem Res 16: 795-803.

Lai JCK, Rimpel-Lamhaouar K, Cooper AJL (1989) Differential inhibition of mitochondrial dehydrogenases by fatty acyl-CoAs. Ann NY Acad Sci 573: 420-422.

Lazo O, Contreras M, Hashmi M, Stanley W, Irazu C, Singh I (1988) Peroxisomal lignoceroylCoA ligase deficiency in childhood adrenoleukodystrophy and adrenomyeloneuropathy. Proc Natl Acad Sci USA 85(20): 7647-7651.

Moore KH, Koen AE, Hull FE (1982) $\beta$-Hydroxy fatty acid production by ischemic rabbit heart: distribution and chemical states. $J$ Clin Invest 69: 377-383.

Moore KH, Decker BP, Schreefel FP (1988) Hepatic hydrolysis of octanoyl-CoA and valproylCoA in control and valproate-fed animals. Int $J$ Biochem 20: 175-178.

Moore KH, Dandurand DM, Kiechle FL (1992) Fasting induced alterations in mitochondrial palmitoyl-CoA metabolism may inhibit adipocyte pyruvate dehydrogenase activity. Int $J$ Biochem 24: 809-814.

Muller-Hocker J, Walther JR, Bise K, Pongratz D, Hubner G (1984) Mitochondrial myopathy with loosely coupled oxidative phosphorylation in a case of Zellweger syndrome. Virchows Arch (Cell Pathol) 45: 125-138.

Naider S, Moser HW (1990) Peroxisomal disorders. Neurol Clin 8: 507-528.

Poulos A (1989) Lipid metabolism in Zellweger syndrome. Prog Lipid Res 28: 37-51.

Rahmatullah M, Roche TE (1985) Modification of bovine kidney pyruvate dehydrogenase kinase activity by CoA esters and their mechanism of action. $J$ Biol Chem 260: 1014610152.

Robinson BH, MacMillan H, Petrova-Benedict R, Sherwood G (1987) Variable clinical presentation in patients with defective $\mathrm{E}_{1}$ component of pyruvate dehydrogenase complex. $J$ Pediatr 111: 525-533.

Roels F, Pauwels M, Poll-The BT et al (1988) Hepatic peroxisomes in adrenoleukodystrophy and related syndromes. Cytochemical and morphometric data. Virchows Archiv A; Pathol Anat 413: 275-285.

Roscher AA, Hoefler S, Hoefler $G$ et al (1989) Genetic and phenotypic heterogeneity in disorders of peroxisome biogenesis - a complementation study involving cell lines from 19 patients. Pediatr Res 26: 67-72.

Sarnat HB, Machin G, Darwish HZ, Rubin SZ (1983) Mitochondrial myopathy of cerebrohepato-renal (Zellweger) syndrome. Can J Neurol Sci 10: 170-177.

Schofield PJ, Griffiths LR, Rogers SH, Wise G (1980) An improved method for the assay of platelet pyruvate dehydrogenase. Clin Chim Acta 108: 219-227.

Schulz H (1991) Beta oxidation of fatty acids. Biochim Biophys Acta 1081: 109-120.

Shepherd D, Garland DB (1969) Citrate synthase from rat liver. Methods Enzymol 13: 11-13.

Smith PK, Krohn RI, Hermanson GT et al (1985) Measurement of protein using bicinchoninic acid. Anal Biochem 150: 76-85.

Smith SJ, Saggerson ED (1979) Regulation of pyruvate dehydrogenase activity in white adipocyte mitochondria by palmitoyl carnitine and citrate. Int $J$ Biochem 10: 785-790.

Trijbels JMF, Berden JA, Monnens LAH et al (1983) Biochemical studies in the liver and muscle of patients with Zellweger syndrome. Pediatr Res 17: 514-517.

Veloso D, Veech RL (1974) Stoichiometric hydrolysis of long chain acyl-CoA and measurement of the CoA formed with an enzymatic cycling method. Anal Biochem 62: 449-460. 
Versmold HT, Bremer HJ, Herzog V et al (1977) A metabolic disorder similar to Zellweger syndrome with hepatic acatalasia and absence of peroxisomes, altered content and redox state of cytochromes and infantile cirrhosis with hemosiderosis. Eur $J$ Pediatr 124: $261-275$.

Wanders RJ, von Roermund CW, van Witland MJ et al (1988) Direct demonstration that the deficient oxidation of very long chain fatty acids in X-linked adrenoleukodystrophy is due to an impaired ability of peroxisomes to activate very long chain fatty acids. Biochem Biophys Res Commun 153: 618-624.

Wanders RJA, van Roermund WT, Shutgens RBH et al (1990) The inborn errors of peroxisomal $\beta$-oxidation. A review. J Inher Metab Dis 13: 4-36.

Whitehouse S, Cooper RH, Randle PJ (1974) Mechanism of activation of pyruvate dehydrogenase by dichloroacetate and other halogenated carboxylic acids. Biochem $J$ 141: 761-774.

Williams HL, de Kort TFM, Trijbels FJM, Monnens LAH, Veer Kamp JH (1978) Determination of pyruvate oxidation rate and citric acid cycle in human leucocytes and fibroblasts. Clin Chem 24: 200-203.

Wilson GN, Holmes RD, Custer J et al (1986) Zellweger syndrome: Diagnostic assays, syndrome delineation and potential therapy. Am J Med Genet 24: 69-82.

Wolff J, Nyhanf WL, Powell $\mathbf{H}$ et al (1986) Myopathy in an infant with a fatal peroxisomal disorder. Pediatr Neurol 2: 141.

\section{ANNOUNCEMENT}

The First European Paediatric Congress, organized under the auspices of 17 European National Paediatric Societies, will be held in Paris, France on March 9-12, 1994, at the Palais de Congres, Port Maillot. Symposia will be organized around six themes:

Endocrinology/Diabetes, Gastroenterology/Nutrition, Genetics/ Metabolism, Immunology, Neurology and Perinatology.

Plenary sessions, satellites symposia and posters will complement the six theme-related symposia. For further information, contact the Organizing Secretariat:

\section{Mercure Communication \\ 9 Avenue Matignon \\ 75008 P ARIS \\ France}

Phone: (33) 1.42.99.17.70/(33) 1.42.99.17.71/(33) 1.42.99.17.72

Fax: (33) 1.45.63.25.68 